\title{
Isolamento de Campylobacter jejuni em feto ovino abortado: relato de caso
}

\author{
[Isolation of Campylobacter jejuni from ovine aborted fetus: case report] \\ A.C. $\operatorname{Vargas}^{1}$, M. Cecim ${ }^{1}$, L.R. Viana ${ }^{1}$, D.A. Spricigo ${ }^{1}$, M.M. Costa $^{2}$ \\ ${ }^{1}$ Departamento de Medicina Veterinária Preventiva - Universidade Federal de Santa Maria \\ Faixa de Camobi, km 9 \\ 97105-900 - Santa Maria, RS \\ ${ }^{2}$ Universidade Federal do Rio Grande do Sul - Porto Alegre, RS
}

\begin{abstract}
RESUMO
Relata-se o isolamento de Campylobacter jejuni de um feto ovino abortado no terço final da gestação. Em uma semana, observaram-se quatro casos de aborto em ovelhas com quatro meses de gestação. Imediatamente após o terceiro aborto, um dos fetos foi submetido a exame patológico, quando se realizou a colheita do conteúdo do abomaso para análise bacteriológica. À necropsia, somente foram evidenciadas alterações autolíticas. Apenas na microaerofilia encontrou-se crescimento bacteriano puro com características morfo-tintoriais de Campylobacter sp., identificado fenotípica e molecularmente como $C$. jejuni. Alerta-se para a possibilidade de quadros de abortos em ovinos serem causados por esse patógeno.
\end{abstract}

Palavras-chave: Campylobacter jejuni, ovino, aborto, PCR

\begin{abstract}
Campylobacter jejuni was isolated from aborted ovine fetus at the end of gestation. Three abortion cases within a week and another fourth case one month later were observed. Immediately after the third case, one fetus was submitted to necropsy and samples from abomasal content were collected for bacteriological analysis. At necropsy, only post-mortem and autolytic lesions were observed. Under microaerophilic conditions, a pure bacterial growth was obtained and identified by morphological and tintorial characteristics as Campylobacter sp., being the isolate confirmed as C. jejuni, by phenotypic and molecular assays. This is an alert for the possibility of this pathogen cause abortion in ovine.
\end{abstract}

Keywords: ovine, Campylobacter jejuni, abortion, PCR

\section{INTRODUÇ̃̃OO}

Os casos mais freqüentes de aborto infeccioso em ovinos são por Chlamydia psittaci, Campylobacter spp. e Toxoplasma gondii (Allen e Borkowski, 1999). Além desses agentes, estão associados com o quadro de aborto Listeria monocytogenes, Brucella ovis e agentes virais, tais como o vírus da doença das mucosas e parainfluenza 3 (Riet-Corrêa e Méndez, 2001).

A infecção por C. jejuni é uma importante causa de aborto em ovinos, mostrando manifestações semelhantes às observadas no aborto por C. fetus subsp. fetus e $C$. coli. Essa bactéria ocasionalmente induz aborto em cães, caprinos e

Recebido para publicação em 29 de setembro de 2003

Recebido para publicação, após modificações, em 3 de agosto de 2004

E-mail: agueda@ccr.ufsm.br 
outros animais (Garcia e Brooks, 1993). No Brasil, não foram encontrados relatos de isolamento desse agente em ovinos. Scarcelli et al. (2001) relataram, pela primeira vez, seu isolamento em aborto de cadela.

As ovelhas podem adquirir a infecção via oral a partir de várias fontes, tais como: fezes de ovinos portadores, aves e água não tratada (Delong et al., 1996; Diker et al., 2000). Uma infecção oral por alta carga do agente leva à rápida bacteremia, que não dura mais que 72 horas. Então, ele é disseminado para os linfonodos mesentéricos, trato gastrintestinal, vesícula biliar e baço (Walt, 1994). Segundo Hirsh (1999), o agente atinge o útero grávido, especialmente nos estádios finais de gestação. Após incubação, que pode levar dois meses, provoca placentite que progride para infecção do feto (fluido amniótico) e, posteriormente, aborto. A placenta, os fluídos e o feto representam a principal fonte de infecção para animais susceptíveis, pela alta carga de contaminação (Hirsh, 1999). Ovelhas que abortam apresentam grave endometrite purulenta, vasculite e placentite necropurulenta. Fetos abortados apresentam grave broncopneumonia purulenta e necrose hepática multifocal. A morbidade em surtos de diarréia em cordeiros de engorda pode alcançar 30\%. Muitas ovelhas apresentam diarréia moderada antes da primeira ocorrência de aborto. Em surtos, $10 \%$ ou mais das ovelhas podem abortar ou, nessas condições, pode ocorrer nascimento de cordeiros fracos (Walt, 1994). Ovinos e caprinos tornam-se imunes após o aborto (Smibert, 1978).

Este trabalho teve o objetivo de relatar o isolamento de Campylobacter jejuni em feto ovino abortado.

\section{CASUÍSTICA}

Em junho de 2002, em um rebanho Texel de 22 ovelhas, no município de Itaara, Rio Grande do Sul, observaram-se quatro casos de aborto em uma semana. Imediatamente após o terceiro caso, o feto foi submetido à necropsia, quando se realizou a colheita do conteúdo do abomaso para análise bacteriológica. A amostra, incubada em meio de transporte e enriquecimento (TEM) (Lander, 1990) a $37^{\circ} \mathrm{C}$ por $72 \mathrm{~h}$, foi semeada em ágar sangue $\mathrm{n}^{\circ} 2$ (Oxoid) e incubada em aerofilia e microaerofilia $\left(10 \% \mathrm{CO}_{2}, 6 \% \mathrm{O}_{2}, 84 \% \mathrm{~N}_{2}\right)$ por 72 horas a $37^{\circ} \mathrm{C}$. A caracterização fenotípica foi realizada de acordo com Nachamkin (1995). A caracterização molecular foi pela reação da polimerase em cadeia (PCR) no DNA termoextraído das colônias isoladas, do DNA extraído do conteúdo do abomaso e do TEM inoculado com conteúdo do abomaso. Foram utilizados oligonucleotídeos (CL2, 5'-TGA CGC TAG TGT TGT AGG AG-3') e (CR3, 5'-CCA TCA TCG CTA AGT GCA AC-3'), descritos por Wang et al. (1999). A mistura para reação constou de: $2,5 \mu \mathrm{l}$ de tampão de Taq $10 \mathrm{X}(10 \mathrm{mM}$ Tris, $50 \mathrm{mM} \mathrm{KCl}, 2,5 \mathrm{mM} \mathrm{MgCl}_{2}$ ), $200 \mu \mathrm{M}$ de dNTPs, $1 \mu \mathrm{l}$ de cada um dos iniciadores (30pmol), 1U de Taq DNA polimerase ${ }^{1}$ e $1 \mu l$ de DNA extraído. Para amplificação, as amostras foram submetidas à desnaturação a $95^{\circ} \mathrm{C}$ por $3 \mathrm{~min}$, seguida de 25 ciclos constantes de desnaturação a $95^{\circ} \mathrm{C}$ por $15 \mathrm{seg}$, anelamento a $48^{\circ} \mathrm{C}$ por $15 \mathrm{seg}$, extensão a $72^{\circ} \mathrm{C}$ por $30 \mathrm{seg}$, e extensão final a $72^{\circ} \mathrm{C}$ por $10 \mathrm{~min}$. Os produtos amplificados foram visualizados em gel de agarose $(1,3 \%)$, corados com brometo de etídeo $(5 \mathrm{mg} / \mathrm{ml})$ sob luz ultravioleta. Como controle positivo, foi utilizado DNA termoextraído de amostra de referência de Campylobacter jejuni utilizada no laboratório (SB 75/00).

\section{DISCUSSÃO}

À necropsia foram evidenciadas alterações autolíticas. No cultivo sob condições de microaerofilia, a $42^{\circ} \mathrm{C}$ e $37^{\circ} \mathrm{C}$, houve crescimento bacteriano puro e significativo com características morfo-tintoriais compatíveis com Campylobacter sp. A amostra não cresceu em aerofilia e nem a $25^{\circ} \mathrm{C}$. Apresentou-se inerte em GOF e não produziu $\mathrm{H}_{2} \mathrm{~S}$ em TSI e SIM. Em ágar MacConkey, foi positivo para catalase e oxidase, reduziu nitrato e demonstrou sensibilidade ao ácido nalidíxico e resistência à cefalotina.

O agente foi isolado em cultura pura do conteúdo do abomaso pré-enriquecido em meio TEM. Sabe-se que o isolamento também é possível a partir da placenta ou de outros órgãos do feto (Walt, 1994).

Pela PCR específica para $C$. jejuni, foi possível a

${ }^{1}$ CENBIOT (UFRGS) - Porto Alegre - RS - Brasil 
identificação de uma banda única de aproximadamente $402 \mathrm{pb}$ no DNA extraído da cultura e da amostra de referência (Fig. 1). A mesma banda foi observada na PCR do TEM e do conteúdo do abomaso. A PCR multiplex foi utilizada para a identificação de $C$. jejuni e $C$. coli em falhas reprodutivas de várias espécies animais (Wesley et al., 1997).

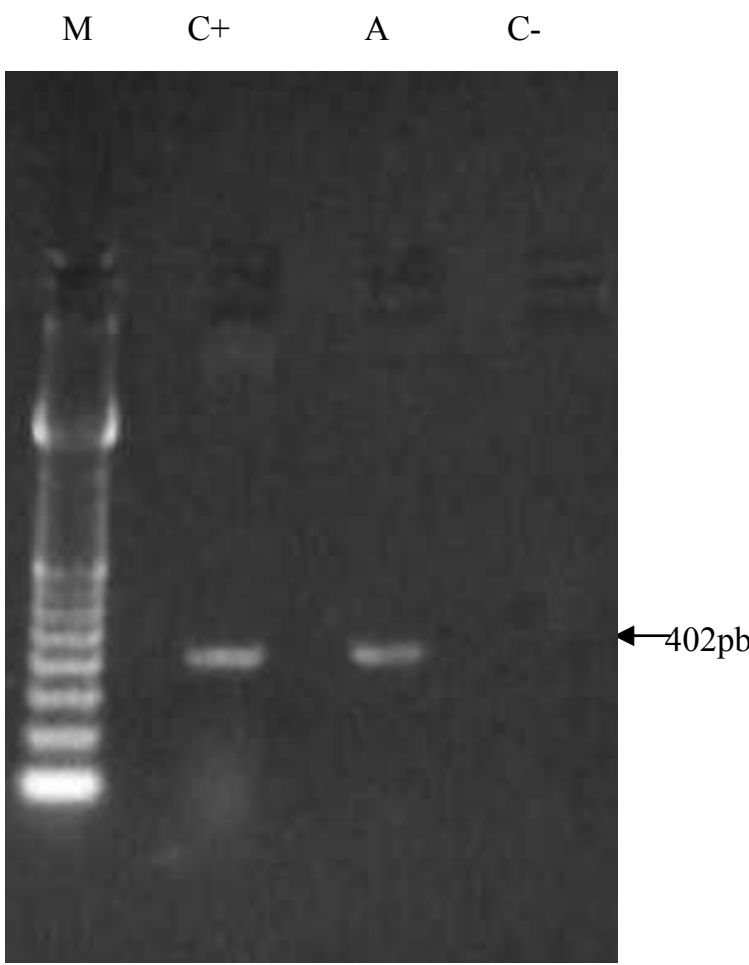

Figura 1. PCR específico para Campylobacter jejuni. (M) Marcador de massa molecular ladder 100 pares de base100pb (Amersham Pharmacia Biothec), $(\mathrm{C}+)$ controle positivo (C. jejuni 75/00), (A) amostra e (C-) controle negativo.

A rapidez da identificação do agente etiológico pela detecção do seu DNA, em comparação ao método bacteriológico, torna a PCR uma alternativa prática aos laboratórios de diagnóstico. Essa técnica elimina o tempo de incubação, isolamento e testes bioquímicos em microrganismos de crescimento fastidioso, com poucas características bioquímicas para identificação, como é o caso de bactérias do gênero Campylobacter (On e Harrington, 2001).

$\mathrm{Na}$ investigação epidemiológica desse surto, supõe-se que a contaminação dos ovinos tenha ocorrido devido à presença de galinhas soltas na propriedade, as quais se alimentavam e bebiam água junto com as ovelhas. $\mathrm{O}$ isolamento de $C$. jejuni das fezes de cordeiros normais e de aves presentes nos criatórios pode ser significativo em estudos sobre a fonte de contaminação em aborto ovino (Smibert, 1978).

A ocorrência de abortos nos rebanhos ovinos pode ser alta, o que demonstra a importância da infecção por $C$. jejuni no desempenho reprodutivo (Walt, 1994). As fêmeas que não abortaram receberam oxitetraciclina na dose de $75 \mathrm{mg}$ /ovelha dia, misturada ao suplemento alimentar por 14 dias. Após o início do tratamento, não ocorreram mais abortos. Cordeiros de ovelhas tratadas tiveram peso ao nascer adequado para a raça e não apresentaram alterações clínicas. Segundo Walt (1994), os abortos podem ser controlados por injeção diária de $4 \mathrm{mg} / \mathrm{kg}$ de eritromicina seguida por injeção intramuscular de oxitetraciclina de longa ação. A administração oral de $75 \mathrm{mg} / \mathrm{kg} /$ dia de clortetraciclina por 14 dias também é efetiva no controle de surtos de aborto. Em um estudo com isolados humanos e de várias espécies animais, testes in vitro demonstraram susceptibilidade de C. jejuni à gentamicina e ao cloranfenicol e resistência variada à sulfonamida, norfloxacina, eritromicina, ampicilina e tetraciclina (Aquino et al., 2002).

Tratando-se do primeiro relato no Brasil, alertase para a possibilidade de quadros de abortos em ovinos serem causados por esse patógeno. Há necessidade da implementação de medidas de controle, tendo em vista os prejuízos econômicos advindos e o risco em saúde pública por seu potencial zoonótico (Garcia e Brooks, 1993; Wassenaar e Newell, 2000).

\section{REFERÊNCIAS BIBLIOGRÁFICAS}

ALLEN, M.J.; BORKOWSKI, G.L. The laboratory- Small ruminant. New York: CRC, 1999. 161p.

AQUINO, M.H.C.; FLIGUEIRAS, A.L.L.; FERREIRA, M.C.S. et al. Antimicrobial resistance and plasmid profiles of Campylobacter jejuni and Campylobacter coli from human and animal sources. Lett. Appl. Microbiol., v.34, p.149-153, 2002. 
DELONG, W.J.; JAWORSKI, M.D.; WARD, A.C.S. Antigenic and restriction enzyme analysis of Campylobacter spp associated with abortion in sheep. Am. J. Vet. Res., v.57, p.163-167, 1996.

DIKER, K.S.; ESENDAL, O.M.; AKAN, M. Epidemiology of ovine Campylobacter infection determined by numerical analysis of electrophoretic protein profiles. J. Vet. Med., v.47, p.739-740, 2000.

GARCIA, M.M.; BROOKS, B.W. Campylobacter. In: GYLES, C.L.; THOEN, C.O. Pathogenesis of bacterial infections in animals. 2.ed. Ames: Iowa State University, 1993. p.262272.

HIRSH, D.C. Campylobacter-Arcobacter (Reproductive tract). In: HIRSH, D.C.; ZEE, Y.C. Veterinary microbiology. Malden: Blackwell Science, 1999. p.192-195.

LANDER, K.P. The development of a transport and enrichment medium for Campylobacter fetus. Br. Vet. J., v.146, p.327-333, 1990.

NACHAMKIN, I. Campylobacter and Arcobacter. In: MURRAY, P.R.; BARON, E.J.; PFALLER, M.A. et al. Manual of clinical microbiology. Washington: ASM, 1995. p.483491.

ON, S.L.; HARRINGTON, C.S. Evaluation of numerical analysis of PFGE DNA profiles for differentiating Campylobacter fetus subspecies by comparison with phenotypic, PCR and $16 \mathrm{~S}$ rDNA sequencing methods. J. Appl. Microbiol., v.90, p.285-293, 2001.
RIET-CORRÊA, F.; MÉNDEZ, M.C. Mortalidade perinatal em ovinos. In: RIETCORRÊA, F.; SCHILD, A.L.; MÉNDEZ, M.C. et al. Doenças de ruminantes e eqüinos. 2.ed. São Paulo: Varela, 2001. v.2, p.417-470.

SCARCELLI, E.; PIATTI, R.M.; CARDOSO, $M$. et al. Polimerase chain reaction (PCR) of Campylobacter jejuni isolated from the female dog abortion. First report in Brazil. In: CONGRESSO BRASILEIRO DE MICROBIOLOGIA, 21., 2001, Foz do Iguaçu. Anais... Rio de Janeiro, 2001. p.496. (Resumo).

SMIBERT, R.M. The genus Campylobacter. Ann. Ver. Microbiol., v.32, p.673-709, 1978.

WALT, M.L. Campylobacter jejuni infection. In: COETZER, J.A.W.; THOMSON, G.R.; TUSTIN, R.C. Infectious diseases of livestock with special reference to Southern Africa. United Kingdom: Oxford, 1994. p.1025-1029.

WANG, H.; FARBER, J.M.; MALIK, N. et al. Improved PCR detection of Campylobacter jejuni from chicken rinses by a simple sample preparation procedure. Int. J. Food Microbiol., v.52, p.39-45, 1999.

WASSENAAR, T.; NEWELL, D.G. Genotyping of Campylobacter spp. Appl. Environ. Microbiol., v.66, p.1-9, 2000.

WESLEY, I.V.; SANDERSON, T.P.; LARSON, D.J. et al. Application of multiplex polymerase chain reaction for rapid identification of Campylobater jejuni and C. coli associated with reproductive failure. Am. J. Vet. Res., v.58, p.1070-1075, 1997. 